Primljeno: 24.2.2021.

Prihvaćeno: 31.7.2021.

DOI: $10.36506 /$ av.64.5

\title{
Rajmund Lampreht
}

Selnica ob Dravi, Slovenija

rajmundl@gmail.com

\section{KRONIKA GRBA OBITELJI FUX IZ METLIKE (CHRONIK ZUM WAPPENS DES GESCHLECHTS FUX): ANALIZA VJERODOSTOJNOSTI}

UDK: 929.52Fux, obitelj

929.642Fux

929.642:929Fux

929.52Fux(497.4Metlika)

Izvorni znanstveni rad

Autor članka obraduje kroniku metličke obitelji Fux, s grbom, koja je u obiteljskom vlasništvu već nekoliko generacija i koja je bila općenito prihvaćena kao konačna cinjenica. Autor je analizirao i provjerio podatke iz kronike te razjasnio tko je njezin autor $i$ kakvim je prevarantskim metodama izigrao obitelj, sugerirajuci i da se radi o plemićkoj obitelji. Istovremeno je objasnio sve bitne elemente u kronici, kao i izvor grba.

Ključne riječi: obitelj Fux; Metlika; heraldika; obiteljski grb Fux; Hermann Julius Hermann; Johann Joseph Fux; krivotvorina

\section{Uvod}

Godine 2015. kontaktirala me je osoba koja je željela izradu obiteljskoga stabla. Tom prilikom predala mi je obiteljsku kroniku koja je bila u obitelji već više generacija i prenošena je iz naraštaja u naraštaj. Napisana je na njemačkom jeziku, goticom. U njoj je nepoznati autor opisivao korijene spomenute obitelji unazad do 16. stoljeća, navodeći osobe pomoću kojih je htio dokazati da je obitelj Fux iz Metlike dobila svoj grb već u 16. stoljeću. Bitni aspekti njegove argumentacije sadrže sljedeće tvrdnje: 
1. Braća Niklas i Viktor Fux primili su grb u 16. stoljeću.

2. Jedan od članova obitelji iz 18. stoljeća bio je i poznati skladatelj Johann Joseph Fux.

3. U 19. stoljeću obitelj se sastoji od velikoga broja srodnika.

4. Posljednji predstavnici obitelji upisani u kroniku potječu iz druge polovice 19. stoljeća, kada autor utvrđuje navodnu plemenitost obitelji Fux iz Metlike.

Pritom se je pojavio problem diskontinuiteta, jer su u kronici nedostajale cijele generacije, pa je bilo potrebno provjeriti dokaze o svim zapisima te utvrditi njihova autora. Za savjet sam se obratio Claussu J. Billetu, specijalistu za heraldiku iz Njemačke. Po detaljnijem pregledu kronike i grba Billet mi je savjetovao da ih usporedim s kronikama Hermanna Juliusa Hermanna. Njih nije bilo moguće naći, ali pomoću dostupne literature o Hermannu i njegovu radu i vremenskoga okvira nastanka njegovih krivotvorina bilo je moguće gotovo sigurno tvrditi da je baš Hermann Julius Hermann bio tvorac dokumenta predstavljenoga u ovom članku. Detaljnijim uvidom u taj dokument, koji nije ni grbovnica ni rodoslovlje, nego nasumično nabrajanje osoba koje nisu bile u srodstvu, bilo je također moguće opovrgnuti tezu o "plemenitom" podrijetlu obitelji Fux iz Metlike. Pritom je autor članka istražio rodoslovne podatke pripadnika obitelji Fux iz Metlike te dokazao njihovu prisutnost u tom gradu već od 17. stoljeća. Ali, kao što to obično biva, tek poslije objave nekoga povijesnoga članka njegov autor obično dobiva povratne informacije od različitih osoba koje su tako ili drugačije povezane s temom rada i koje imaju više podataka kojima bi ispunili i razjasnili mnoge nejasnoće.

\section{Vanjski opis i sadržaj Kronike grba obitelji Fux iz Metlike}

Julius Hermann bio je vrlo lukav krivotvoritelj, koji je svoje kronike sastavljao tako da su imale autentičan izgled. Osim što je citirao grbovnice te tako ostavljao dojam autentičnosti, navodio je podatke o predcima, koje je dobio od stranaka ili župnika. Postupak je bio takav da je Hermann kontaktirao župnika u Metliki i molio ga za ispis podataka o zadnje tri generacije predaka obitelji Fux. ${ }^{1}$ Župnik je za to koristio stanje duša (status animarum), crkvenu knjigu koja, međutim, nije pouzdan izvor, jer su zapisi ondje sastavljeni na temelju usmene predaje, a dobiveni podatci nisu provjeravani. Zato dio članova obitelji nije bio evidentiran u stanju duša, pa ih župnik nije ni prenio krivotvoritelju. U najstarijem stanju duša župe Metlika bilo je zabilježeno da se Karl Fux nalazi u Grazu. To se je međutim odnosilo na stanje u trenutku nastanka toga zapisa, ${ }^{2}$ a ne na mjesto rođenja.

\footnotetext{
1 Takav je bio uobičajeni Hermannov način rada te je tako bilo i u ovom slučaju, iako u metličkom župnom arhivu nije pronađen njegov dopis.

2 To je bilo između 1820. i 1835., kada je Karl Fux studirao i živio u Grazu. Župa Metlika, Status animarum, 1820., mjesto Metlika.
} 
Župnik i Julius Hermann podatak iz te knjige stanja duša krivo su interpretirali, pa je tako kasnije nastao (netočan) podatak da je Karl Fux rođen u Grazu. ${ }^{3}$ Međutim, prema matičnim knjigama, Karl Fux rođen je u Metliki 1802. godine. ${ }^{4}$ Bio je sin Jakoba Fuxa i Frančiške rođ. Žagar (Schagar). ${ }^{5}$ Oko 1820. otišao je na studij prava u Graz, zbog čega je metlički župnik, sastavljajući popis župljana, napisao da se nalazi »u Gradcu«. Poslije završenoga školovanja ostao je u gradu i radio kao pripravnik u nekom uredu, a oko 1831. napredovao je u suca. U Grazu se je 1829. oženio Antonijom Wanka, kćeri Taddeusza Wanke, austrijskoga pukovnika češkoga podrijetla. ${ }^{6}$ Obitelj je ondje ostala još nekoliko godina. Tamo mu je rođeno i prvo troje (po nekim izvorima četvero djece). Najkasnije 1837. (između 1836. i 1837.) vratio se je u Metliku te preuzeo od već bolesne ${ }^{7}$ majke Frančiške, drugi put udate Šebenik, poslove gradskoga poštara (njem. postmeister).

Julius Hermann to nije mogao razabrati iz popisa župljana i nije dalje istraživao. Podatak da je Karl »u Gradcu« bio mu je dovoljan dokaz, i tako je za obitelj Fux iz Metlike sastavio "kroniku" u kojoj ih je povezao s austrijskim skladateljem Johannom Josephom Fuxom iz Graza, braćom Viktorom i Niklasom Fuxom i drugim osobama s prezimenom Fux koje nisu bile povezane s obitelji Fux iz Metlike.

Prije vanjskoga opisa i opisa sadržaja Kronike obitelji Fux potrebno je dati nešto informacija o njezinu tvorcu. Julius Hermann (1868.-1953.), također i Hermann Hermann, bio je krivotvoritelj iz Beča koji je prodavao izmišljene kronike te im dodavao grbovnice obitelji koje su slučajno imale isto prezime. Sam je bio uvjeren da svatko ima pravo doći do vlastitoga grba (Slika 1). Istovremeno je upozoravao da samo stručnjak može i mora izvesti istraživanje, ${ }^{8}$ pa je u Beču ustanovio Institut za genealogiju i heraldiku. ${ }^{9}$ Svojim izmišljenim kronikama opskrbio je velik broj obitelji. Samo između 1898. i 1905. sastavio je i prodao najmanje 696 kronika. ${ }^{10}$ Policijski istražitelji koji su ga zbog toga uhitili

\footnotetext{
3 U stanju duša iz 1856. zabilježeno je da je rođen u Grazu (sic!). Župa Metlika, Status animarum 1856.-1878., mjesto Metlika.

4 U matičnoj knjizi rođenih upisan je kao Carolus Joseph Fux. NŠAL, fond Metlika, Matična knjiga rođenih Metlika, 1801.-1808., fol. 14.

5 NŠAL, fond Metlika, Matična knjiga rođenih Metlika, 1801-1808., fol. 14. Predci Karla Fuxa imali su od 17. stoljeća nasljedno pravo upravljanja važnom poštanskom postajom u Metliki, koja je slala poštu iz Karlovca prema Ljubljani, Grazu i Beču. Tu dužnost obavljali su sve do 70-ih godina 19. stoljeća.

6 Diözesanarchiv Graz-Seckau, fond Maria Trost, Matična knjiga vjenčanih Maria Trost, 1809.-1830.

7 Franšička je umrla 1840., tri godine kasnije. NŠAL, fond Metlika, Matična knjiga umrlih Metlika, 1825.-1842. Njezin muž i Karlov otac Jakob umro je već 1813., i zato je njegova žena Frančiška naslijedila mjesto poštarice. NŠAL, fond Metlika, Matična knjiga umrlih Metlika, 1802.-1816.

8 Hermann Hermann, Genealogie und Heraldik bürgerlicher Familien Österreich-Ungarns: II. Band (Wien: H. Hermann, 1902), str. VI.

9 “Die Wappenfabrik des Hermann Hermann," Das Vaterland, br. 6 (24. listopada 1905): str. 6.

10 Jürgen Arndt, Der Wappenschwindel - seine Werkstätten und ihre Inhaber: Ein Blick in die heraldische Subkultur (Berlin: Degener\&Co., 1997): str. 58-61.
} 
zaključili su da ih je vjerojatno bilo i više, jer su kod pretrage Hermannove kuće našli oko deset tisuća omotnica na kojima je već bila napisana adresa primatelja. ${ }^{11}$

Poslije samo dva dana rasprave, bečki sud je 24. listopada 1905. osudio Juliusa Hermanna zbog njegove kriminalne djelatnosti na pet mjeseci zatvora. No, on je po izlasku nastavio raditi jer je većina svjedoka na suđenju izjavila da se ne osjećaju izigranima ni prevarenima te da još uvijek rabe njegovu kroniku i grb. ${ }^{12}$ Časopisi su njegovu kriminalnu djelatnost opisivali kao "tvornicu za gradanske grbove”, ${ }^{13}$ a njega su nazivali „heraldičkim pjesnikom“" (der Wappendichter). ${ }^{14}$ Julius Hermann svojim je strankama predstavljao brojne izmišljene prednosti koje im donose njegovi radovi. Tako je jednoj stranci rekao da će s kronikom i grbom moći dobiti posao upravljača posjeda kod kakvoga višega plemića. ${ }^{15}$

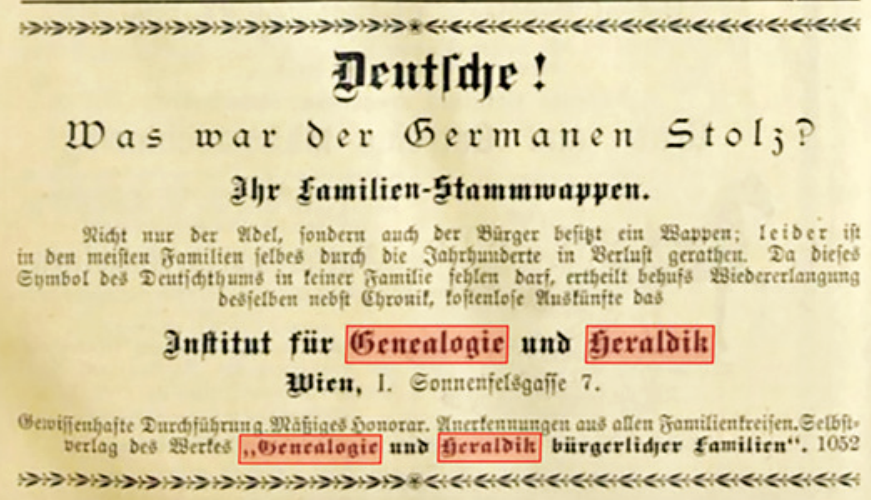

Slika 1. Oglas Juliusa Hermanna u jednom časopisu, ${ }^{16}$ s tekstom koji u prijevodu glasi: "Nijemci! Što je bio ponos Germana? Njihov obiteljski grb. Ne samo plemići, nego su takoder gradani posjedovali svoj grb. Taj je tijekom stoljeća pao u zaborav. Taj simbol nijemstva ${ }^{17}$ ne smije nedostajati u nijednoj obitelji. Vise besplatnih informacija dobit ćete u Institutu za genealogiju $i$ heraldiku. Pažljivo istraživanje, umjereni honorari i priznanje svih obitelji."

\footnotetext{
11 “Der Wappendichter Hermann," Die Zeit, br. 5 (24. listopada 1905): str. 4.

12 "Eine Fabrik für bürgerliche Wappen," Illustrierte Kronen Zeitung, br. 4 (25. listopada 1905): str. 5.

13 “Eine Fabrik für bürgerliche Wappen," str. 5.

14 "Der Wappendichter Hermann," str. 4.

15 "Eine Fabrik für bürgerliche Wappen," str. 5.

16 “Anzeige Institut für Genealogie und Heraldik." Deutsches Nordmährerblatt, br. 9 (25. siječnja 1902): str. 6.

17 u originalu: Deutschthums.
} 


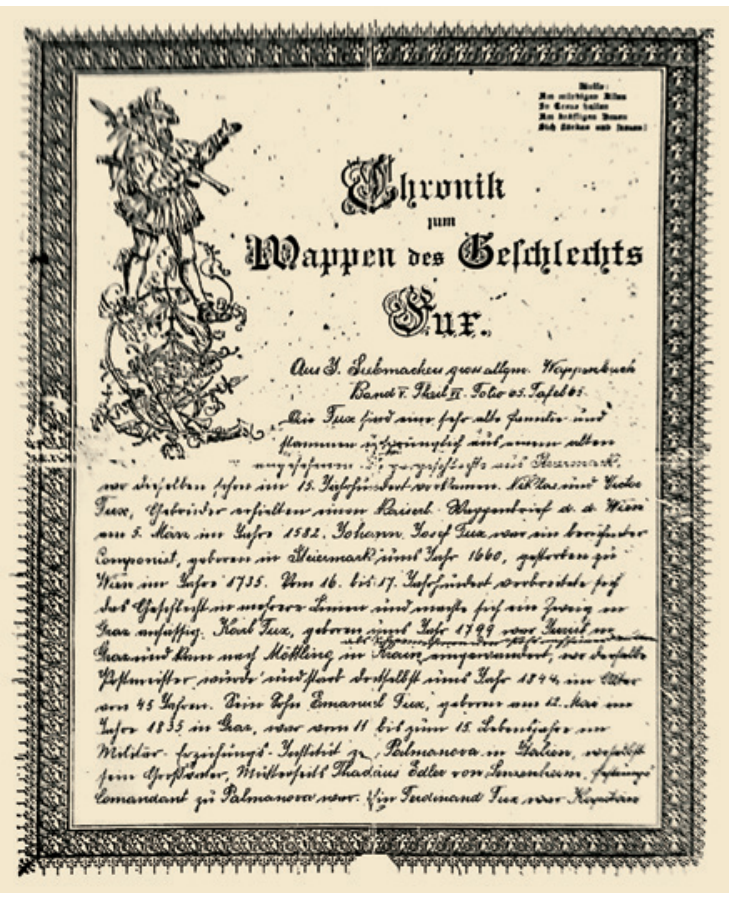

Slika 2. Prva stranica kronike koju je sastavio Julius Hermann za obitelj Fux (Osobni arhiv Saše Fux). Kronika je napisana na otisnutom obrascu koji djeluje "starinski". Na početku počinje navodenjem Siebmacherova grbounika te tako ostavlja dojam da je riječ o stručnom djelu.

Hermanova djela opisana su također u knjizi Der Wappenschwindel, seine Werkstätten und ihre Inhaber ("Heraldička prijevara, njezine radionice i njihovi vlasnici”). ${ }^{18}$ Karakteristična za Hermannove kronike bila je uporaba papira ukrašenih otisnutim okvirom i figurom lovca ili vojnika koji nosi u ruci luk, rog, koplje ili vijenac. Glavni natpis kronike bio je bez iznimke: Chronik des Geschlechts (Slika 2). Međutim, Julius Hermann nije djelovao samostalno. Pomagao mu je izvjesni Raimund Günther, krivotvoritelj iz Salzburga, koji mu je unaprijed slao te otisnute papire. Günther je djelovao vrlo profesionalno. Svoja djela oglašavao je u časopisima, a za njega je radilo mnogo akvizitera koji su nudili primjerke kronika i katalog te tako pridobivali stranke. Djelovali su po cijeloj Monarhiji, pa je tako i obitelj Fux došla u kontakt s krivotvoriteljima. Cijena krivotvorene kronike iznosila je od 30 do 300 kruna. $^{19}$

Naslov je Hermannove kronike Chronik zum Wappens des Geschlechts Fux (Slika 2). Dokument se sastoji od dva lista s dekorativnim rubom. U lijevom kutu nalazi se ilustracija koja je vjerojatno ukrašavala sve Hermannove kronike koje mu je pripremao Raimund Günther iz Salzburga. Bradati muškarac i ukriv-

\footnotetext{
18 Arndt, Der Wappenschwindel, str. 58-61.

19 “Die Wappenfabrik des Hermann Hermann," str. 6; “Eine Fabrik für bürgerliche Wappen," str. 5.
} 
ljeni konusni oblik završetka njegova šešira jedini su elementi koji podsjećaju na grb braće Niklasa i Viktora Fuxa. Vjerojatno je sve kronike ukrašavao i moto u gornjem desnom kutu, s tekstom: "Čvrsto vjerovati u dostojanstvo tradicije, a jačati i veseliti se kroz snagu novoga! ${ }^{20}$ Poslije naslova Chronik zum Wappens des Geschlechts Fux naznačeno je da se kronika obitelji Fux nalazi u Siebmacherovu grbovniku (5. svezak, 6. dio, list 65, tabela 65).

Sadržaj je napisan na njemačkom, a ovo je prijevod na hrvatski:

„Fuxovi su veoma stara obitelj koja potječe od staroga i uglednoga građanskoga roda iz Štajerske, gdje ih nalazimo već u 15. stoljeću. Braća Niklas i Victor primili su od cara grbovnicu, izdanu u Beču 5. ožujka 1582. godine. Johann Joseph Fux bio je znameniti skladatelj, rođen u Štajerskoj oko 1660., a umro u Beču oko 1735. godine. Od 16. do 17. stoljeća taj se je rod razvio u više grana i jedna od njih naselila se je u Grazu. Karl Fux, rođen oko 1799. godine, bio je jurist u Grazu i došao je u Metliku u Kranjskoj, gdje je preuzeo poštu po svojoj majci te 1844. umro kao poštar u dobi od 45 godina. Njegov sin Emanuel Fux, rođen 12. svibnja 1835. u Grazu, boravio je od svoje 11. do 15. godine u vojničkom zavodu u Palmanovi u Italiji, gdje je njegov djed po majčinoj strani, Tadej pl. Lenzenheim, bio komandant utvrde ${ }^{21}$ Palmanova. Neki Ferdinand Fux bio je natporučnik ${ }^{22}$ u pješačkom puku br. 35 .

Emanuel Fux, više puta zabilježen i kao Fuchs, bio je 1853. potporučnik ${ }^{23}$ u pješačkom puku br. 58. Karl Fux bio je kadet u pješačkom puku br. 17, a Oto Fux potporučnik u pješačkom puku br. 11. Imenovani se je već 1893 . naselio u Grazu u Vrtnoj ulici br. 15. Fuxovi još i danas žive kao građani u različitim zemljama.

Grb: u zlatnom su tri crne linije. U gornjem kutu je lisica u trku. Ukras u otvorenoj i izbočenoj kacigi je bradati muškarac u crnoj odjeći s pet zlatnih dugmeta, zlatnim pojasom i zlatnim ukrivljenim konusnim šeširom. U desnoj ruci drži vinogradarski nož i viseći grozd plave boje.

Značenje: tri crne kose linije u zlatnom znače čvrstinu i snagu. ${ }^{24}$ Lisica u trku znači slobodu, lukavost i požudu. Otvorena izbočena kaciga znači plemenito podrijetlo obitelji. ${ }^{25}$ Bradati, u crno obučeni muškarac s pet zlatnih dugmeta, zlatnim pojasom i zlatnim svijenim konusnim šeširom te plavim grozdom u desnici i vinogradarskim nožem dokazuje mušku lozu. ${ }^{26}$ Plavi grozd znači rast i

\footnotetext{
20 Am würdigen Alten in Creuz halten, am kräftigen Neuen, Sich stärken und freuen!

${ }^{21}$ Festungscomandant.

22 Kapitän Leutnant.

23 Unterleutnant.

24 Festigkeit und Stärke.

25 Die gute Abkunft des Geschlechts.

26 Die männliche Stamm-haltung.
} 


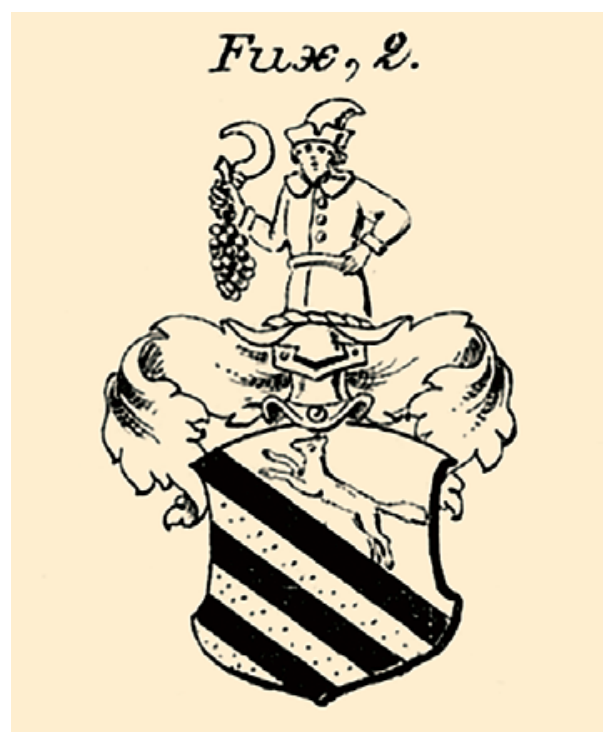

Slika 3. Grb Niklasa i Viktora Fuxa u Siebmacherovu grbovniku.

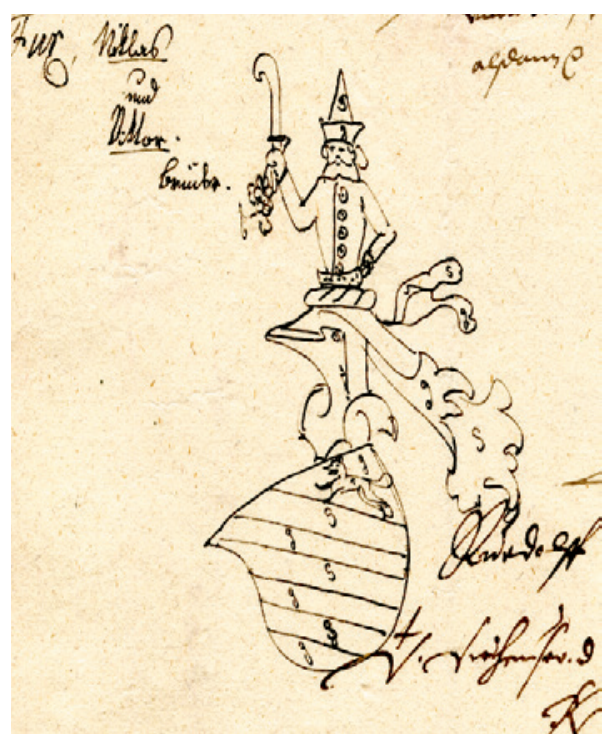

Slika 4. Skica grba za Niklasa i Viktora Fuxa iz 1582. u Austrijskom državnom arhivu.

uspijevanje, vinogradarski nož marljivost i ustrajnost. Crno znači poniznost, ${ }^{27}$ zlatno ugled i gospodstvo. $\aleph^{28}$

\section{Kritička analiza Hermannove kronike}

Braća Niklas i Viktor Fux bili su istinite osobe koje su dobile plemstvo u 16. stoljeću. Taj je podatak Hermann našao, kao što navodi, na početku Siebmacherova grbovnika. Međutim, njegovo određenje stranice na kojoj se grb obitelji Fux nalazi u grbovniku nije točno: J. Siebmacher: Wappenbuch, 5. svezak, 6. dio, folija 65, tabela 65 ne sadrži grb Fuxovih, nego grbove obitelji Frey, Freyberger, Freyperger, Freyheimer, Freyhofer, Freyssgemuet, Frickh, Fridereich, Friderich, Friess, Fritsch, Fritz i Frölich. Grbovi Fuxovih nalaze se u tabeli 67 (Slika 3). ${ }^{29}$ U Austrijskom držannom arhivu u Beču (Haus- Hof -, und Staatsarchiv Österreich) nalazi se i izvorno pismo iz 1582. koje sadrži skicu grba (Slika 4).$^{30}$ Iz pisma nije moguće utvrditi tko su bili Niklas i Viktor Fux ni gdje

\footnotetext{
27 Demuth.

28 Ansehen und Hoheit.

29 Johann Siebmacher, Siebmacher's grosses und allegemeines Wappenbuch: Bd. 5: Theil 6 (Nürnberg: Bauer \& Raspe, 1901), str. 65, tabela 67.
}

30 AT-OeStA/AVA Adel RAA 131.28. Wappenbrief Brüder Fux Niklas und Viktor. 
Wappen: in B. eine schrägrechtsgestellte $\mathrm{g}$. Wecke. Helm: sitzender n. Fuchs nit abhängendem Schweife, zwischen zwei g. - b. Büffelhörnern, Decken und Binde: b. $\mathrm{g}$.

Fux 2, Niclas und Victor, Gebrüder, erhielten einen kaiserlichen Wappenbrief d. d. Wien 5. März 1582.

Wappen: in G. drei erniedrigte \# Schrägbalken, im Obereck ein laufender n. Fuchs. Helm: wachsender bärtiger Mann in \# Kleidung mit fünf $\mathrm{g}$. Knöpfen, g. Gürtel und g.-gestülptem Spitzhat, in der Rechten ein Weinmesser und eine abhangende b. Traube haltend. Decken: \#g.

Slika 5. Opis grbovnice u Hermannovoj kronici sličan je opisu iz Siebmacherova grbovnika (Wappenbuch) u tabeli 67 na strani 65 (5. svezak, 6. dio).

su živjeli. Autoru članka nije bilo moguće naći druge dokumente u kojima bi se dotične osobe uopće spominjale.

Hermann je izabrao braću Fux između desetak drugih osoba istoga prezimena koji su dobili plemstvo tijekom stoljeća. Treba priznati da Hermann braću Fux ne dovodi u rodbinsku vezu s obitelji Fux iz Metlike, nego samo nabraja neke izabrane osobe kako bi dao "vjerodostojnost" kronici koju je sastavio za obitelj Fux iz Metlike.

Sljedeća osoba koja se spominje u Hermannovoj kronici, i koja se također ne povezuje izravno s obitelji Fux iz Metlike, skladatelj je Johann Joseph Fux (Slika 6). ${ }^{31}$ Bio je rođen oko 1660. u Hirtenfeldu, općina Langegg kod Graza, Štajerska (Steiermark). Bio je sin seljaka Andreasa i Ursule Fux. Johann Joseph bio je oženjen, ali nije imao djece, što znači da je s njime njegova linija izumrla. Također nije posjedovao obiteljski grb. ${ }^{32}$ Novija istraživanja o skladatelju donose zanimljive podatke o njegovu životu i srodnicima, koji su svi bili nepismeni seljaci. ${ }^{33}$ No, Julius Hermann nije istraživao skladateljevu obitelj ni njegov život. Bilo mu je važno samo to da se u kronici nalazi poznata ili slavna osoba.

Hermann dalje piše da se je rodbina Fuxovih (ne piše kojih, od braće Niklasa i Viktora ili kojih drugih) tijekom dva stoljeća razgranala i da se je jedna

\footnotetext{
31 “Johann Joseph Fux," Wikipedia, pristupljeno 22. kolovoza 2021., https://en.wikipedia.org/wiki/ Johann_Joseph_Fux.

32 "Biografie," Johann Joseph Fux Archiv, pristupljeno 22. kolovoza 2021., https://www.fux-archiv.com/ biografiel.

33 Michael Lorenz, "Fux Documents," Researchgate (rujan 2016), pristupljeno 22. kolovoza 2021., https://www.researchgate.net/publication/315117172_Fux_Documents.
} 


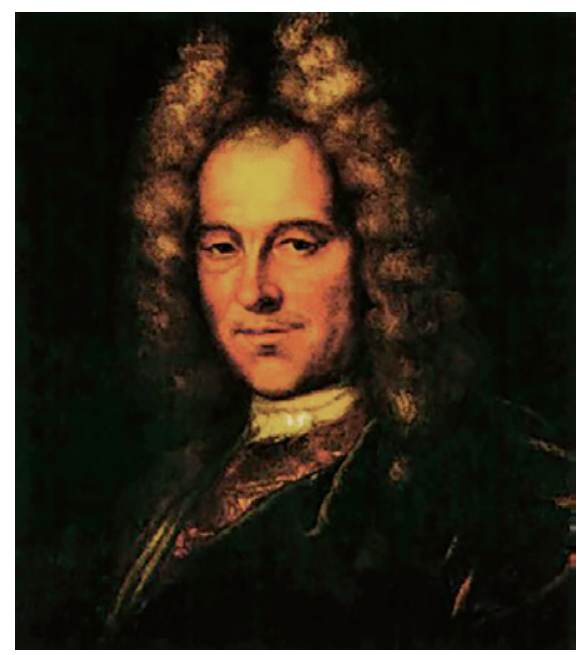

Slika 6. Johann Joseph Fux

grana naselila u Grazu. Tu spretno ubacuje Karla Fuxa, jurista iz Graza, navodeći da je rođen oko 1799. godine. Da kasnije navedeni podatci o Karlu i njegovu sinu Emanuelu nisu točni, mogli bismo pomisliti da je riječ o nekom drugom Karlu Fuxu. Međutim, u matičnim knjigama župe Metlika naveden je 9. travnja 1802. kao datum rođenja Karla Fuxa. Karl je zaista bio pravnik i sudac u Grazu, ali se je oko 1837. vratio u Metliku, kako piše i u Hermannovoj kronici. Nije zabilježeno da se je vratio radi preuzimanja mjesta poštara ${ }^{34}$ od tada već bolesne majke, kao što su tu službu ranije obavljali njegovi predci (otac, djed, pradjed i dr.). ${ }^{35}$ Tako je postignut dojam da je Karl Fux bio iz Graza. Hermann dalje navodi da je Karl Fux umro 1844., što je točno, ali nije točno da je imao 45 godina (imao je 42 godine). Razlika proizlazi iz pogrešnoga bilježenja datuma rođenja u Hermannovoj kronici. ${ }^{36}$

Nakon toga Hermann navodi Emanuela Fuxa, sina Karla Fuxa, za kojega piše da je od 11. do 15. godine bio vojni pitomac u Palmanovi, gdje je službovao

\footnotetext{
34 Mjesto poštara bilo je vjerojatno mnogo unosnije od mjesta suca. Obitelj Fux u tri je stoljeća zakupa mjesta poštara tako povećala svoje bogatstvo da je bila jedna od najimućnijih obitelji u tom dijelu Kranjske.

35 Najstariji istraženi predak Karla Fuxa bio je Joannis Fux, koji je rođen oko 1670., a bio je također poštar (Postmeister) u Metliki. Matične knjige župe Metlika ne navode točan datum ni mjesto rođenja i smrti Joannisa Fuxa, ali bilježe njegovo vjenčanje i rođenje dvoje djece.

36 Još danas moguće je vidjeti nadgrobnu ploču Karla Fuxa na vanjskom zidu prezbiterija južne crkve kod Tri Fare kod Rosalnice. Međutim i tamo je moguće naći koju grešku, kao što je primjerice godina smrti 1847. To dokazuje da je nadgrobna ploča bila uzidana nešto kasnije. Karl Fux umro je 5. prosinca 1844. NŠAL, fond Metlika, Matična knjiga umrlih Metlika, 1843-1867.
} 
njegov djed po majčinoj strani, Thaddeusz Wanka von Lenzenheim, kao komandant utvrde. Datum je Emanuelova rođenja u Grazu točan - to je 12. svibnja 1835. godine. Sjetimo se da je njegov otac Karl tada još bio sudac u Grazu, gdje je rođeno prvih troje ili četvero od sedmero djece Karla Fuxa i Antonije rođ. Wanka von Lenzenheim. O Emanuelu smo našli mnogo podataka. U njima nije spomenuto njegovo školovanje u Palmanovi, ali je poznato da je naslijedio posao poštara od svoje majke Antonije rođ. Wanka von Lenzenheim, koja je kao udovica, također kao njezina svekrva, godinama vodila taj posao. Prvi put oženio se je Johanom (Netty) Parma iz trgovačke obitelji, koja je potjecala iz Monastera kod Akvileje. ${ }^{37}$ Johana je umrla od tifusa 1863., pa se je Emanuel oženio godinu dana kasnije Karolinom Kapelle, kćeri Johana Kapellea (također i Capelle), upravnika "komende" njemačkoga viteškoga reda u Metliki i zastupnika u kranjskom zemaljskom saboru.

Sljedeća osoba koju Hermann spominje neki je Ferdinand Fux, koji je bio natporučnik (Kapitän Leutnant) u pješačkom puku (Infanterie Regiment) br. 35. $\mathrm{Ni}$ on nije u srodstvu s Fuxovima iz Metlike jer toga imena nema u obitelji ni u jednoj generaciji od 1670. godine.

Potom navodi Emanuela Fuxa, koji je 1853. bio potporučnik (Unterleutnant) u pješačkom puku br. 58. Taj Emanuel nije mogao biti Karlov sin Emanuel Fux, jer je on u to vrijeme bio poštar u Metliki i upravljao velikim imetkom naslijeđenim od predaka. Zadnje su osobe koje navodi Karl Fux, kadet u pješačkom puku br. 17, i Otto Fux, potporučnik u pješačkom puku br. 11, koji se je 1893. naselio u Grazu. Ni jedan od njih nije bio potomak obitelji Fux iz Metlike. ${ }^{38}$

Poslije navođenja tih osoba Hermann opisuje grb koji je navodno dobila obitelj Fux iz Metlike. Opis je u osnovi isti kao kod braće Niklasa i Viktora Fuxa iz Siebmacherova grbovnika. Novost je zadnji dio (njem. Bedeutung, "značenje"), u kojem objašnjava značenje crne i zlatne boje u grbu te elemenata kao što su lisica u trku, bradati muškarac, plavi grozd i dr.

$\mathrm{Na}$ kraju moramo pokušati naći i odgovore na neka pitanja koja se nameću sama od sebe. Je li ta Hermannova kronika krivotvorina? Kada detaljnije analiziramo Hermannovu kroniku, vidimo da je kod navođenja rodbinskih veza ipak bio oprezan. Naime, nikoga od spomenutih osoba nije doveo u direktnu vezu s Fuxovima iz Metlike, osim Karla i Emanuela Fuxa, pri čemu izričito navodi da je Emanuel bio Karlov sin, što je točno. Sve spomenute osobe postojale su i

\footnotetext{
37 Antonio Parma iz Monastera oženio se je Elizabetom Shemuga iz Novske (Referentna zbirka Petra Hawline, Škofja Loka, Slovenija, Obitelj Sartori). Prvi njihov sin Ivan Kapistran rođen je 1821. u Drenovu Boku u Slavoniji. Poslije su se preselili u Metliku, gdje su rođene još četiri kćeri, među njima i Johana (Netty).

38 U obitelji Fux iz Metlike poslije suca Karla Fuxa rođen je još jedan Karl. To je bio u Grazu prvorođeni sin Karla Fuxa i Antonije rođ. Wanka von Lenzenheim. Međutim, on je umro u Metliki kao 19-godišnji mladić 1 . svibnja 1856. godine.
} 
živjele su u različitim vremenskim razdobljima, od braće Niklasa i Viktora Fuxa iz 16. stoljeća, preko skladatelja Johanna Josepha Fuxa, koji je živio krajem 17. i početkom 18. stoljeća, do različitih osoba prezimena Fux iz 19. stoljeća. Krivotvorina (ili samo spretna kompilacija) je u tom da je u dokument spretno ubacio dva člana obitelji Fux iz Metlike. Tako je stvorio dojam da pripadaju obitelji Fux koja je preko braće Niklasa i Viktora Fuxa dobila plemstvo već u 16. stoljeću. Međutim, s tom braćom, koja jedina imaju plemstvo, nije rodbinski povezana ni jedna druga osoba koja je spomenuta u kronici.

Znamo li tko je od obitelji Fux iz Metlike naručio tu kroniku i zašto? Na to pitanje teško je odgovoriti sa sigurnošću, ali s obzirom na obiteljsku povijest možemo pretpostaviti tko je to bio. S obzirom na to da je Hermann izradio najviše svojih krivotvorina između 1898. i 1905., vjerojatno je riječ o Karlovu sinu Emanuelu Fuxu (1835.-1915.), koji je spomenut i u Hermannovoj kronici. Na pitanje zašto ju je naručio nije tako teško odgovoriti. Njegova majka bila je plemkinja (rođ. von Lenzenheim), njegova sestra bila je udata za plemića (von Šfflay), ${ }^{39}$ teta također, ${ }^{40}$ a i bratić je bio plemić. ${ }^{41}$ On sam, koji je naslijedio sve bogatstvo Fuxovih, nije imao plemstvo. Zato je na neki način došao u kontakt (vjerojatno preko putujućih "akvizitera") s Hermannom te vjerojatno naručio dokument u kojem bi bilo moguće i Fuxove povezati s plemstvom. Isto je tako vjerojatno da je upravo Emanuel Fux dao osnovne podatke o sebi i svojem ocu koje je poslije Hermann uključio u Kroniku obitelji Fux.

Na kraju je potrebno hrvatskomu čitatelju predočiti i moguće podrijetlo obitelji Fux. Nije potrebno ići u Štajersku u Graz ili Češku i tamo tražiti Fuxove koji bi bili rodbinski povezani s obitelji Fux iz Metlike. Potrebno je samo pogledati u bližnje Kočevje, gdje su već stoljećima bili naseljeni Kočevski Nijemci zvani Kočevarji (Gottscheer). Njih su iz Koruške i istočnoga Tirola naselili grofovi Ortenburški već oko 1330. godine. Njihove jezične značajke i njihova prezimena u slovenskoj su historiografiji dobro istraženi. Pored mnogih prezimena koja postoje još i danas (Schwaiger, Weiss, Strurm i dr.) u 16. stoljeću postoji u urbarima više obitelji s prezimenom Fux ili Fuchs. ${ }^{42}$

\footnotetext{
39 Antonija Fux, kći Antonije (rođ. Wanka von Lenzenheim) i Karla Fuxa vjenčala se je s Danijelom Šufflayem, sinom Filipa Šufflaya Otruševečkoga.

40 Karlova sestra Frančiška Fux (1808.-1847.) udala se je za jednoga pripadnika obitelji Sladović von Sladojević.

41 Sin Frančiške rođ. Fux i Emanuelov bratić bio je Ferdinand Sladović von Sladojević, koji je od svoje majke naslijedio vlastelinstvo Črnomelj i živio je u Hrvatskoj.

42 Usp. Ivan Simonič, "Migracije na Kočevskem u luči priimkov," Etnolog: Glasilo Etnografskega muzeja $v$ Ljubljani 7 (1934): str. 107-138.
} 


\section{Zaključak}

Prilikom istraživanja povijesti obitelji Fux iz Metlike stranka mi je dostavila obiteljsku kroniku koja je u obitelji čuvana već više generacija te je prenošena iz generacije u generaciju. Napisana je njemačkom goticom. U njoj je nepoznati autor opisivao korijene spomenute obitelji unazad do 16. stoljeća te spominjao osobe pomoću kojih je htio dokazati da je obitelj Fux dobila svoj grb već u 16. stoljeću. U kronici je navedeno da je obitelj u 16. stoljeću primila grb, s braćom Niklasom i Viktorom Fux, da je Johann Joseph Fux bio je poznati skladatelj u 18. stoljeća, te su navedene brojne osobe prezimena Fux u 19. stoljeću. Problem je spomenute kronike nedostatak kontinuiteta u slijedu generacija, pa je bilo potrebno provjeriti sve dokaze i otkriti njezina autora.

Posredno je utvrđeno da je autor te obiteljske kronike izvjesni Hermann Julius Hermann, krivotvoritelj iz Beča, koji je prodavao izmišljene kronike te im dodavao grbovnice obitelji koje su slučajno imale isto prezime. $U$ tu svrhu ustanovio je u Beču Institut za genealogiju i heraldiku. Svojim izmišljenim kronikama opskrbio je velik broj obitelji, a samo između 1898. i 1905. dokazano je sastavio i prodao 696 kronika.

Hermann nije djelovao samostalno. Pomagao mu je izvjesni Raimund Günther, krivotvoritelj iz Salzburga, koji mu je slao unaprijed tiskani papir. Günther je djelovao vrlo profesionalno. Svoje je radove oglašavao u časopisima, a za njega je radila četa akvizitera koji su nosili sa sobom primjere i katalog te tako pridobivali stranke. Djelovali su po cijeloj Monarhiji, pa je tako i obitelj Fux došla u kontakt s njima. Cijena krivotvorene kronike iznosila je od 30 do 300 kruna.

Kronike koje je sastavljao Hermann nemaju obilježja znanstvenih radova. Hermann je sastavljao obiteljske kronike iz koristoljublja, a da bi ostvario taj cilj nije birao ni sredstva ni izvore. Svoje je stranke zavaravao radi postizanja prikladne cijene.

Grb koji su dobili braća Niklas i Viktor Fux u 16. stoljeću Hermann je opisao u svojoj kronici, dodao skladatelja Johanna Josepha Fuxa i još nekolika osoba koje nisu bile u srodstvu te uključio dva člana obitelji Fux iz Metlike (Karla Fuxa i sina Emanuela). Tako je stvorio dojam da su Karl Fux i sin Emmanuel (koji je vjerojatno bio i naručitelj) u rodbinskoj vezi s ostalim navedenim osobama, te je to prodao obitelji. 


\section{POPIS IZVORA}

\section{Arhivsko gradivo}

Nadškofijski arhiv Ljubljana

NŠAL, fond Metlika, Matična knjiga rođenih Metlika.

NŠAL, fond Metlika, Matična knjiga umrlih Metlika.

NŠAL, fond Metlika, Matična knjiga vjenčanih Metlika.

\section{Župa Metlika}

Status animarum.

Osobni arhiv Saše Fux, Ljubljana

Referentna zbirka Petra Hawline, Škofja Loka

Obitelj Sartori.

Diözesanarchiv Graz-Seckau

Diözesanarchiv Graz-Seckau, fond Maria Trost, Matična knjiga vjenčanih Maria Trost. Maria Trost.

Diözesanarchiv Graz-Seckau, fond Maria Trost, Matična knjiga rođenih

Haus-, Hof-, und Staatsarchiv Österreich

AT-OeStA/AVA Adel RAA 131.28. Wappenbrief Brüder Fux Niklas und Viktor.

\section{Službena glasila i tisak}

Deutsches Nordmährerblatt (Olomouc), 1902.

Illustrierte Kronen Zeitung (Beč), 1905.

Das Vaterland (Beč), 1905.

Die Zeit (Beč), 1905. 


\section{Literatura}

"Anzeige Institut für Genealogie und Heraldik." Deutsches Nordmährerblatt, br. 9 (25. siječnja 1902): str. 6.

Arndt, Jürgen. Der Wappenschwindel-seine Werkstätten und ihre Inhaber: Ein Blick in die heraldische Subkultur. Berlin: Degener\&Co., 1997.

“Biografie." Johann Joseph Fux Archiv. Pristupljeno 22. kolovoza 2021. https://www.fux-archiv.com/biografie/.

“Der Wappendichter Hermann.” Die Zeit, br. 5 (24. listopada 1905): str. 4.

"Die Wappenfabrik des Hermann Hermann." Das Vaterland, br. 6 (24. listopada 1905): str. 6.

"Eine Fabrik für bürgerliche Wappen.” Illustrierte Kronen Zeitung, br. 4 (25. listopada 1905): str. 5.

Hermann, Hermann. Genealogie und Heraldik bürgerlicher Familien Österreich-Ungarns: I. Band. Wien: H. Hermann, 1899.

Hermann, Hermann. Genealogie und Heraldik bürgerlicher Familien Österreich-Ungarns: II. Band. Wien: H. Hermann, 1902.

"Johann Joseph Fux." Wikipedia. Pristupljeno 22. kolovoza 2021. https:// en.wikipedia.org/wiki/Johann_Joseph_Fux.

Lorenz, Michael. "Fux Documents." Researchgate (rujan 2016). Pristupljeno 22. kolovoza 2021. https://www.researchgate.net/publication/315117172_ Fux_Documents.

Siebmacher, Johann. Siebmacher's grosses und allegemeines Wappenbuch: Bd. 5: Theil 6. Nurnberg: Bauer \& Raspe, 1901.

Simonič, Ivan. "Migracije na Kočevskem u luči priimkov." Etnolog: Glasilo Etnografskega muzeja v Ljubljani 7 (1934): str. 107-138. 
Summary

CHRONICLE OF THE FUX FAMILY FROM METLIKA COAT OF ARMS (CHRONIK ZUM WAPPENS DES GESCHLECHTS FUX): THE ANALYSIS OF AUTHENTICITY

While researching the history of the Fux family from Metlika a family member gave me the chronicle that has been kept in the family from generation to generation. It is written in German in Gothic script. The unknown author of the chronicle describes the family roots back to the $16^{\text {th }}$ century, mentioning individuals who were to serve as the proof that the Fux family obtained their coat of arms as early as the $16^{\text {th }}$ century.

The most important claims from the chronicle are:

- The family obtained their coat of arms in the $16^{\text {th }}$ century with brothers Niklas and Viktor Fux.

- The $18^{\text {th }}$ century family ancestor Johann Joseph Fux was a renowned composer.

- The chronicle states many individuals with the surname Fux in the $19^{\text {th }}$ century.

The problem with the chronicle is the lack of continuity among the successive generations, hence, it is necessary to check all the evidence and discover its author. It has been directly ascertained that the author of the chronicle is a certain Hermann Julius Hermann, a forger from Vienna selling bogus chronicles to which he added coat of arms belonging to families that happened to have the same surname. For that purpose he established The Institute for Genealogy and Heraldry in Vienna. He supplied numerous families with false chronicles; for the period between 1898 and 1905 alone it has been proven that he drew up and sold 696 chronicles.

Hermann did not act on its own. A certain Raimund Günther, a forger from Salzburg, was his aide, who supplied him with paper that was printed in advance. Günther was a consummate professional in his activities. He advertised his work in magazines and had numerous sales agents in his employment. They had with them examples and a catalogue in order to attract clients. They were active across the entire Habsburg Monarchy, which is how the Fux family got in contact with them. The price for the forged chronicle was between 30 and 300 crowns.

Chronicles drawn up by Hermann Julius Hermann are not scientific work. Hermann created them entirely for self-interest and did not choose means or sources in order to achieve that goal. He deceived his clients for the purpose of achieving a suitable price.

The coat of arms obtained by Niklas and Viktor Fux in the $16^{\text {th }}$ century was described by Julius Hermann in his chronicle, adding the composer Johann 
Joseph Fux and several other individuals who were not related, and he also included two members of the Fux family from Metlika (Karl Fux and his son Emanuel). In that way he created the impression that Karl and Emanuel Fux (the latter most probably placing the order) are related to other named individuals and sold this to the family.

Keywords: the Fux family; Metlika; Hermann Julius Hermann; Johann Joseph Fux; forgery 